\title{
Analysis of Stress Events in Students of The Faculty of Public Health, Muhammadiyah University of Jakarta in Online Learning During The Covid19 Pandemic in 2021
}

\author{
${ }^{1}$ Alifya Fitri Ananda, ${ }^{2}$ Alvi Fauzia, ${ }^{3}$ Ari Laras, ${ }^{4}$ Astri Maretta, ${ }^{5}$ Munaya Fauziah \\ Faculty of Public Health, Muhammadiyah University of Jakarta \\ K.H. Ahmad Dahlan St, Cireundeu, Ciputat, South Jakarta, 15419 \\ E-mail: kikiarilaras0345@gmail.com
}

\begin{abstract}
Online learning is a learning activity by utilizing the internet network, local area network as a method of interacting in learning such as delivering material. Stress in this study is defined as a condition experienced by a person when there is a mismatch between the demands received and the ability to overcome them. This research is qualitative research using the Rapid Assessment Procedure design. The selection of samples or informants uses the principle of appropriateness, selected by purposive method or determines the criteria for informants who can provide information following the research objectives. Online learning has several causes including lack of concentration due to environmental disturbances, unstable internet network, many assignments from lecturers, lack of communication or social interaction. Online learning for FKM UMJ students is influenced by: lack of concentration due to environmental disturbances, unstable internet network, many assignments from lecturers, lack of communication or social interaction. The way to deal with stressful events in online learning can be done by doing positive activities, looking for calm or refreshing, managing time well.
\end{abstract}

Keywords: Covid-19, College Student, Online Learning, Stress 


\section{INTRODUCTION}

The Coronavirus Disease 2019 (COVID-19) epidemic emerged in Wuhan, China, and spread throughout the country in December 2019 (Qiu et al., 2020). According to the World Health Organization (WHO) in January 2020, declared the outbreak of the new coronavirus disease, namely COVID- 19, as a Public Health Emergency of International Concern (Hidayah et al.,2020). Educational institutions that do not escape temporary closures have a direct impact on the teaching and learning process that requires online media. Students as the largest population in educational institutions will certainly feel the impact of the COVID-19 pandemic, where the learning system that is usually carried out face-to-face either on campus or in practice has turned into a network (online) (Hidayah et al., 2020)

Online learning is a learning activity by utilizing the internet network, local area network as a method of interacting in learning such as delivering material (Mustofa et al., 2019). All elements from lecturers, staff, and students must adapt to this condition. This sudden change can certainly cause stress for students (Sari MK, 2020) in (Adrian, Putri and Suri, 2020).

At first, some students responded positively to online learning, but as the learning process progressed, students experienced some difficulties. These difficulties include unsupportive signals, some students lack quotas, many distractions when studying at home, students feel less focused on learning without direct interaction with lecturers and other students, the material presented is difficult to understand, lack of readiness of lecturers in preparing the material (Gunadha \& Rahmayunita, 2020; Utami et al., 2020). Many tasks with short deadlines also make their obstacles in online learning (Kompas, 2020).

Stress in this study is defined as a condition experienced by a person when there is a mismatch between the demands received and the ability to overcome them. (Muslim, 2020). Anxiety, stress, and depression are common mental disorders with a prevalence of $10-40 \%$ in developing countries. Stress is now an attribute of modern life because stress has become a common and inevitable part of life. Stress can be experienced by someone wherever they are such as family, school, work, and society. Stress can be felt by people of all ages, from children, teenagers, adults, or the elderly. Stress can harm a person's physical and mental (Kupriyanov, 2014). Stress is characterized by physical, emotional, intellectual, and interpersonal symptoms. Difficulty sleeping, tired easily, often feeling tired, muscle tension, and even diarrhea are physical symptoms of stress (Nurmaliyah, 2014). (Jatira and S, 2021)

Some students feel stressed and sad because the network is not stable so they can't attend lectures optimally, some students are worried because they can't afford internet quota, feel pressured because of the many assignments given by the lecturer in a short time, and some final semester students feel frustrated not could graduate on time because the research process and guidance were hampered (Agus Santoso, 2020) in (Fitria, 2013). Objections to the assignments given by the lecturer, these difficulties include unsupportive signals, some students lack quotas, many disturbances when studying 
at home, students feel less focused on learning without direct interaction with lecturers and other students, the material presented is difficult to understand, (Gunadha \& Rahmayunita, 2020; Utami et al., 2020). Many tasks with short deadlines also make their obstacles in online learning (Kompas, 2020). (Jatira and S, 2021).

Students become confused and do not know how to deal with their condition. If this continues, it will affect the mental condition of students which has an impact on decreasing interest in learning, decreasing achievement, decreasing the quality of graduates, and even mental health disorders in students (Giacalone et al., 2020). This results in high stress levels among students harming academic achievement and mental health of students (Kristina. AS, Anna. WW, \& Ika. PS, 2020) in (Fitria, 2013)

The prevalence of students in the world who experience stress is $3871 \%$, while in Asia it is 39.6-61.3\% (Habeeb 2010, Koochaki 2009). Meanwhile, the prevalence of students experiencing stress in Indonesia was 36,771.6\% (Fitasari 2011).(Adrian, Putri and Suri, 2021). The results of a preliminary study conducted on 12 online students related to student stress levels during the COVID-19 pandemic using 7 questions from the DASS-21 questionnaire showed that 2 students experienced severe stress, 5 students experienced moderate stress, 2 students experienced mild stress, and 3 students experience stress in the normal category. (Hidayah et al., 2020). The results to Martaviani's research (2020), stress that occurs in third semester transfer program students can be concluded because of academic guidance, poor time management, and current environmental factors, namely during the pandemic. The results showed that the third-semester transfer program students had mild stress (24.4\%), moderate stress (37.8\%), and severe stress (35.6). Mild anxiety level (21\%), moderate anxiety (12.5\%). (Fitria, 2013)

Online Lectures in the Covid-19 Era and Its Impact on Student Mentality" shows that around $60.5 \%$ of students are ready to adapt to the use of online lecture learning technology but around 59.5\% object to assignments given by lecturers which result in student stress levels of around 60\%, if this is allowed to continue Continuous learning will be fatal in the mental development of students, and as many as $92 \%$ of students choose and prefer face-to-face lectures in class compared to online lectures (Publication Manuscript_Indah Novitasari_S16156 (1)).

Therefore, researchers want to see the perceptions and opinions of FKM UMJ students regarding stress in online learning during the COVID-19 pandemic in 2021.

\section{METHODS}

This research is qualitative research using the Rapid Assessment Procedure design which will be conducted from April to May 2021. The informants are students of the Faculty of Public Health (FKM), University of Muhammadiyah Jakarta strata 1 regular. The data collection technique used in this research is an In-depth Interview (WM). In-depth interviews (WM) were carried out on 5 female 
students and 1 key informant, namely Kaka for the 2016 Regular S1 student level, FKM UMJ. The selection of samples or informants uses the principle of appropriateness, selected by purposive method or determines the criteria for informants who can provide information in accordance with the research objectives. The topic explored in this the study is the perspective of online learning during the COVID-19 pandemic on the incidence of stress in students.

\section{RESULTS AND DISCUSSIONS}

Table 1. The Results of this Research

\begin{tabular}{|c|c|c|c|c|c|}
\hline TOPIC & $\begin{array}{c}\text { MEANING } \\
\text { UNIT }\end{array}$ & CODE & SUB & CATEGORY & THEME \\
\hline $\begin{array}{l}\text { 1. How to do } \\
\text { you feel } \\
\text { about } \\
\text { online } \\
\text { learning } \\
\text { during the } \\
\text { Covid-19 } \\
\text { Pandemic } \\
\text { ? }\end{array}$ & $\begin{array}{l}\text { - Yes, there } \\
\text { are a lot of } \\
\text { things that feel } \\
\text { like they are } \\
\text { very different, } \\
\text { from the } \\
\text { beginning, } \\
\text { face to face, so } \\
\text { everything is } \\
\text { virtual and it's } \\
\text { a bit difficult to } \\
\text { adjust and } \\
\text { when } \\
\text { you're online, } \\
\text { there are more } \\
\text { and more } \\
\text { tasks. } \\
\text { - During the } \\
\text { Covid } \\
\text { pandemic in } \\
\text { online learning } \\
\text { what I feel is } \\
\text { different } \\
\text { from offline } \\
\text { learning, I feel } \\
\text { less effective } \\
\text { in learning, I feel } \\
\text { bored and } \\
\text { bored } \\
\text { - There are } \\
\text { Many } \\
\text { differences } \\
\text { between } \\
\text { face-to- face } \\
\text { and } \\
\text { Online } \\
\text { learning. At } \\
\text { the beginning } \\
\text { of } \\
\text { pandemic, } \\
\text { felt } \\
\text { because it was } \\
\text { all at home, I } \\
\text { thought it was } \\
\text { fun, it seemed } \\
\text { more }\end{array}$ & $\begin{array}{l}\text {-Many } \\
\text { differences, } \\
\text { difficult and } \\
\text { many tasks } \\
\text {-Different, } \\
\text { less effective, } \\
\text { bored and } \\
\text { bored } \\
\text { Many } \\
\text { differences, } \\
\text { happy at } \\
\text { home, many } \\
\text { minuses, } \\
\text { boredom, } \\
\text { need to meet } \\
\text { campus } \\
\text { friends } \\
\text { Decreased } \\
\text { enthusiasm } \\
\text { for learning, } \\
\text { not being } \\
\text { affected by } \\
\text { the } \\
\text { surrounding } \\
\text { environment } \\
\text { There are fun } \\
\text { and there is } \\
\text { no fun like } \\
\text { signals and } \\
\text { lecturers are } \\
\text { too fast }\end{array}$ & $\begin{array}{l}\text {-Different, } \\
\text { difficult, } \\
\text { many } \\
\text { tasks } \\
\text {-Different, } \\
\text { less } \\
\text { effective, } \\
\text { saturated, } \\
\text { happy, bored, } \\
\text { need to meet } \\
\text { friends } \\
\text {-Get down, } \\
\text { don't } \\
\text { focus } \\
\text { happy, not } \\
\text { happy, signal, } \\
\text { fast lecturer }\end{array}$ & $\begin{array}{l}\text {-Big and } \\
\text { difficult } \\
\text { method } \\
\text { difference } \\
\text {-Less effective } \\
\text {-Need } \\
\text { interaction } \\
\text {-Influence the } \\
\text { spirit of } \\
\text { learning } \\
\text {-Learning } \\
\text { support system } \\
\text { disorders } \\
\text { lecture capacity }\end{array}$ & $\begin{array}{l}\text { Stress events } \\
\text { in online } \\
\text { Learning } \\
\text { during the } \\
\text { covid19 } \\
\text { pandemic }\end{array}$ \\
\hline
\end{tabular}




\begin{tabular}{|c|c|c|c|c|c|}
\hline TOPIC & $\begin{array}{c}\text { MEANING } \\
\text { UNIT }\end{array}$ & CODE & SUB & CATEGORY & THEME \\
\hline & $\begin{array}{l}\text { comfortab le, } \\
\text { but after going } \\
\text { through a few } \\
\text { months to } \\
\text { more than a } \\
\text { year, I was } \\
\text { already bored } \\
\text { with this } \\
\text { method, and } \\
\text { there were so } \\
\text { many minuses, } \\
\text { so it was easy } \\
\text { to get bored } \\
\text { and } \\
\text { needed to meet } \\
\text { college friend. } \\
\text { - I feel that } \\
\text { by learning } \\
\text { online, the } \\
\text { enthusias m } \\
\text { decreases, } \\
\text { because they } \\
\text { often lack } \\
\text { focus with the } \\
\text { surroundi ng } \\
\text { environm } \\
\text { ent. } \\
\text { I myself have } 2 \\
\text { things, there } \\
\text { are fun and } \\
\text { unpleasant } \\
\text { things being } \\
\text { able to learn } \\
\text { chili sauce } \\
\text { lying down, } \\
\text { and not happy } \\
\text { about signal } \\
\text { interference } \\
\text { and lecturer } \\
\text { explanatio ns } \\
\text { don't } \\
\text { understand } \\
\text { because it's too } \\
\text { fast }\end{array}$ & & & & \\
\hline
\end{tabular}

The results of this study indicate that there are stressful events in online learning during the COVID-19 pandemic, as the informants assume that online learning during the pandemic is experiencing different difficulties, many tasks, boredom, boredom, reduced enthusiasm for learning, not focus, due to interference from the surrounding environment, that's more or less the meaning of the quote above that was conveyed by a female student informant of FKM UMJ. 
Informants' perceptions of online learning, informants overcome online learning by discussing with friends, searching google, entertaining themselves, increasing physical activity, looking for reference books. The results of the quote above were conveyed by a female student informant from FKM UMJ.

The results of research on informants on how effectiveness in online learning has an unsatisfactory effect, namely the absence of effectiveness in online learning during a pandemic due to disturbances such as unstable networks, homework, and the surrounding environment that result in the ineffectiveness of online learning.

The results of the research in managing time during online learning during the Covid-19 Pandemic showed results such as lectures, organization according to each other, making weekly or daily planners, setting the time with an alarm.

Meanwhile, according to in-depth interviews related to the informant's perception of the level of stress in online learning before and after the Covid-19 on FKM UMJ students showed that there was a difference in the level of stress felt by the informant to be bored, bored, lack of concentration, more assignments, lack of communication with friends. , less able to manage time between college and work. The following is an excerpt from the results of in-depth interviews obtained:

"There's something like that, maybe the difference is that before there was a pandemic, I was tired of doing a lot of work, but I enjoyed being able to chat or play with my friends, and I'm also getting less and less concentrated, I get tired quickly and get bored studying online too" - QM FKM 16

The perception felt by the informant from a physical point of view when many tasks piled up during online learning as the informant assumed said the informant felt more tired, achy, sore eyes, due to too often doing assignments, easily dizzy and also some that his hair fell out. There are so many things that are felt by FKM UMJ students from a physical point of view due to online learning during the COVID-19 pandemic, many complain from a physical point of view. That's more or less the opinion of the informant regarding the physical aspect felt during online learning during the COVID- 19 pandemic.

The results of in-depth interviews showed that during online learning during the covid-19 pandemic, informants experienced differences when online learning was not focused, less effective, signal interference, needed to meet with friends so as not to get bored. That is more or less the result of the quote above that was conveyed by a female student informant of FKM UMJ.

The results of in-depth interviews show that online learning during the covid- 19 pandemic, informants resulted in differences in irregular sleep patterns or staying up late to do tasks with deadlines and piling up tasks, inter-interference or unstable signals, unstable moods that can cause emotions to be out of control. Less than the results from the above quote submitted by a student informant from FKM UMJ. 
Informants stated that the emotional increase in online learning has an impact on the surrounding environment "That's true, sometimes you stay silent, sometimes you take it out on other people and you also think you don't feel good because you are an outlet because you just don't control it"

"Sometimes it has an impact on the people around me."

"Sometimes, if I keep quiet sometimes my sister gets hit, but I often go to find peace outside the house"

Events that occur due to increased emotional angry, fighting, angry that is not clear

"Is it possible that I just get angry with my sister or brother so it's easy to get emotional, the most like that"

"Resulting in fights between me and other people"

"Just an unexplained temper tantrum."

Based on the results of in-depth interviews conducted by several informants in line with the 2020 research by Funsu Andiarna and Estri Kusumawati regarding the effectiveness of online learning, it was found that the ineffectiveness of online learning was caused by students feeling that their understanding of independent learning from reading materials and assignments was unsatisfactory and difficult for students to understand. , signal interference. In previous research, it was stated that internet connection is the main thing in the online teaching and learning process where if there is no adequate internet connection, direct interaction between students and educators does not materialize. (Hamdani \& Priatna, 2020) in(Andiarna, 2020))

Students are required to explore knowledge and understanding of the material independently. Literacy on technology, namely student mastery of technology as a medium for achieving online learning success. Many platforms and online media can be accessed via the internet by teachers and students. Some of the things that become obstacles in the implementation of online learning include limited internet quotas and the unfamiliarity of educators and students in applying it. Intrapersonal communication skills, namely the skills needed by students in interacting with other students as a form of social being even though the online learning process is carried out independently. Skills for independent learning, namely the ability to learn independently in a skilled manner.(Andiarna and Kusumawati, 2020)

Students experience stress when studying online due to the difficulty of understanding the material during online lectures. Difficulties arise not only in terms of skills in using technology but also related to a large workload considering that many courses must be faced during this COVID-19 pandemic. This happens because students are accustomed to face-to-face learning regularly, whereas distance learning was previously only done incidentally. So that this change in learning patterns provides its problems for students. the emergence of pressure and stress on students who do distance 
learning. At this point, the pressure of course becomes heavier, so students experience increased stress. So at this point,(Argahani, 2020)

Stress is characterized by physical, emotional, intellectual, and interpersonal symptoms. Difficulty sleeping, tired easily, often feel tired, muscle tension, and even diarrhea are physical symptoms of stress. (Andiarna, 2020). Stress according to its level is divided into mild, moderate, and severe stress. Mild stress is characterized by being easily tired, unable to relax, this will disappear if stress can be overcome. Moderate stress is indicated by the body's response to feeling like fainting, the body feels like falling, and decreased concentration and memory. Severe stress can cause indigestion, an increasingly loud heart rate, shortness of breath, and a feeling of trembling in the body.(Saffira, Dahliana and Nurdin, 2017)

College students have a high risk of stress and are exposed to various stressors. Stress experienced by students that occur in schools/colleges is called academic stress (Barseli \& Ifdil, 2017). Academic stress on students does not only occur in Indonesia, Wang's research concludes that Chinese students show higher anxiety during the COVID-19 pandemic (Wang \& Zhao, 2020). Changes in curriculum, changes in environmental conditions, new learning climates cause academic stress. Online learning due to the covid-19 pandemic is a new learning climate that is felt by students.(Andiarna and Kusumawati, 2020)

The results of the research conducted by Pawicara et al. showed that students experienced learning saturation due to various factors. These factors include media or material that is less attractive so that the presentation of material during the online learning process is carried out in a monotonous manner. The number of assignments given is accompanied by the provision of material without in-depth explanation. This causes students to misunderstand the material. As a result, there is a feeling of laziness, loss of enthusiasm, stress, difficulty sleeping, tired and boredom with lecture material during online learning. This causes boredom of learning in students. In addition, the influence of a less supportive home learning environment such as crowded, noisy, and uncomfortable also causes boredom in learning.

Efforts to overcome or manage stress today are known as the process of coping with stress. According to Bart Smet, coping has two kinds of functions, namely: Emotional-focused coping and Problem-focused coping. Emotional-focused coping is used to regulate emotional responses to stress. This arrangement is carried out through individual behavior such as the use of alcohol, how to eliminate unpleasant facts, and so on. Meanwhile, problem-focused coping is done by learning new skills or ways to deal with stress. According to Bart Smet, individuals will tend to use this method if they believe they can change the situation, and this method is often used by adults. Talking about efforts to overcome stress, Maramis argues that various actions can be taken for it,(Jannah and Santoso, 2021)

Macan, et al (Harun, 2012) suggest the factors that influence time management, namely: 
1. Understanding of time control, which relates to feelings of being able to manage time and controlling things that can affect the use of time. These are: one's beliefs can affect the use of time and how one perceives time itself

2. Setting goals and priorities, namely what a person's needs and desires are to be completed and how individuals can determine needs according to the priority of tasks needed to achieve goals. These include: setting goals and prioritizing goals objectively.

3. Time management mechanisms, namely the methods used in managing time such as making lists, schedules, and work plans. These include: planning and making schedules.

4. Tendency to be organized, related to improving, changing, and managing the environment in completing tasks. These include the ability to organize work and work environment.

Time management mechanism Time management is carried out by students by taking steps to schedule assignments at certain scheduled hours, relaxing and playing schedules are reduced from the time before being exposed to academic stress, and increasing the work schedule. They choose to overcome their academic stress by prioritizing tasks and speeding up the completion of the task load, after the task is reduced, their academic stress is also automatically reduced. Then the tendency to be organized is seen from setting up a comfortable environment that is easy to concentrate on, building a good mood in making lectures/thesis assignments. From this, it can be said that they have done time management in carrying out activities.

Furthermore, time management strategies are used by students by managing their daily schedules, one of which is a schedule for writing a thesis, looking for references, attending lectures, and scheduling consultations with lecturers. The short time is an opportunity that needs to be maximized for final students to complete college before the Drop Out period. A short period to complete college, causes students to be vulnerable to academic stress. Poor use of time can be a contributing factor to academic stress in these conditions.

Time management efforts to deal with academic stress are done by arranging activity schedules, noting the types of tasks that must be done, preparing before activities, planning effective time to make assignments, looking for task materials, and dividing time between making assignments and taking breaks.

From the description above, it can be understood that time management efforts are carried out to speed up task completion work and reduce the impact of existing academic stress. The role of time management can help students use time as effectively and efficiently as possible not to delay work so that goals can be realized and the academic stress experienced is resolved (Saffira, Dahliana and Nurdin, 2017).

\section{CONCLUSIONS AND SUGGESTIONS}


Based on the results of the author's research, it can be concluded that the incidence of stress in online learning for FKM UMJ students is influenced by: lack of concentration due to environmental disturbances, unstable internet network, many assignments from lecturers, lack of communication, or social interaction. The way to deal with stressful events in online learning can be done by doing positive activities, looking for calm or refreshing, managing time well.

\section{REFERENCES}

Adrian, FA, Putri, VS and Suri, M. (2021) 'The Relationship of Online Learning in the Covid-19 Pandemic Period with Stress Levels of S1 Nursing Students STIKes Baiturrahim Jambi', Baiturrahim Jambi Academic Journal, 10(1), p. 66. doi:10.36565/jab.v10i1.276.

Andiarna, F. (2020) 'Effects of Online Learning on Student Academic

Stress During the Covid-19 Pandemic', Journal of Psychology, 16(2), pp. 139-150.

Andiarna, F. and Kusumawati, E. (2020) 'The Effect of Online Learning on Student Academic Stress During the Covid- 19 Pandemic', Journal of Psychology, 16(2), p. 139. doi: 10.24014/jp.v16i2.10395.

Argaheni, NB (2020) 'Systematic Review: The Impact of Online Lectures During the COVID-19 Pandemic To Indonesian Students', PLACENTUM: Scientific Journal of Health and Its Applications, 8(2), p. 99. doi:10.20961/placentum.v8i2.43008.

Fitria (2013) 'described above, researchers are interested in researching "Description of Stress for Transferred Students in Working on Thesis during the Covid-19 Pandemic, Faculty of Nursing Unand".', Journal of Chemical Information and Modeling, 53(9), pp. 1689-1699.

Hidayah, N. et al. (2020) 'Stress Levels and Coping Strategies for Nursing Students during the Covid-19 Pandemic', Ojs.Unm.Ac.Id, pp. 184-192.

Jannah, R. and Santoso, H. (2021) 'Stress Levels of Students Participating in Online Learning in', Journal of Research and Community Service Vol., 1(1), pp. 194210.

Jatira, Y. and S, N. (2021) 'The Phenomenon of Stress and Habituation of Online Learning during the Covid-19 Pandemic', Educational: Journal of Educational Sciences, 3(1), pp. 35-43. doi:10.31004/edukatif.v3i1.187.

Muslim, M. (2020) 'Moh. Muslim: Stress Management during the Covid-19 Pandemic" 193', Journal of Business Management, 23(2), pp. 192-201.

Saffira, P., Dahliana and Nurdin, S. (2017) 'Time Management Efforts in Overcoming Student Academic Stress', Scientific Journal of Guidance and Counseling Students, 2(2), pp. 27-31. 